Int. J. Electrochem. Sci., 15 (2020) $576-586$

\title{
Influence of Temperature on the Corrosion Behavior of X80 Steel in an Acidic Soil Environment
}

\author{
Yuanhui $\mathrm{Wu}^{1,2, *}$, Suxing Luo ${ }^{1,2}$, Qingsong $\mathrm{Mou}^{1,2}$ \\ ${ }^{1}$ Department of Chemistry and Chemical Engineering, Zunyi Normal College, Zunyi, \\ 563006, P. R. China. \\ ${ }^{2}$ Special Key Laboratory of Electrochemistry for Materials of Guizhou Province, Zunyi, 563006, P. R. \\ China \\ *E-mail: yhwull@126.com
}

doi: $10.20964 / 2020.01 .03$

Received: 8 September 2019 / Accepted: 26 October 2019 / Published: 30 November 2019

The influence of temperature on the corrosion behavior of X80 steel in an acidic soil environment was determined using electrochemical and surface analysis methods. The results revealed that the corrosion rate of X80 steel increased with increasing soil temperature from $25{ }^{\circ} \mathrm{C}$ to $75{ }^{\circ} \mathrm{C}$, and the corrosion rate of X80 steel at $75^{\circ} \mathrm{C}$ was 19 times higher than that at $25^{\circ} \mathrm{C}$. The charge transfer resistance decreased with increasing soil temperature, and the control step for corrosion was the activation polarization process. The kinetics of the corrosion process complied with the Arrhenius law, and the activation energy $\mathrm{E}_{\mathrm{a}}$ was $50.7 \mathrm{~kJ} \cdot \mathrm{mol}^{-1}$. In addition, the compositions of corrosion products consisted of $\mathrm{Fe}_{2} \mathrm{O}_{3}, \mathrm{Fe}_{3} \mathrm{O}_{4}$, $\mathrm{SiO}_{2}$ and $\mathrm{Al}_{2} \mathrm{O}_{3}$.

Keywords: X80 steel; soil; corrosion; temperature

\section{FULL TEXT}

(C) 2020 The Authors. Published by ESG (www.electrochemsci.org). This article is an open access article distributed under the terms and conditions of the Creative Commons Attribution license (http://creativecommons.org/licenses/by/4.0/). 